\title{
Regional Shift in the Global Automotive Sector
}

\author{
Mehmet Cemil Simsek \\ Department of Finance, Banking and Insurance, Karamanoğlu Mehmetbey University, Turkey
}

Copyright $\bigcirc 2019$ by authors, all rights reserved. Authors agree that this article remains permanently open access under the terms of the Creative Commons Attribution License 4.0 International License

\begin{abstract}
The automotive sector accounts for a significant part of the global cross border trade. Therefore, it is to reflect the current economic structure around the world. This study reveals economic characteristics of this significant sector, while considering how cross border trade, production and market of this sector have experienced shifts across regions over the last decade. This study proves that Asia-Pacific region has displayed remarkable growth in terms of automotive imports and exports, and motor vehicle assembly and market over the last decade constituting a larger share of the global automotive sector. On the other hand, European region still leads the global automotive imports and exports.
\end{abstract}

Keywords Automotive Imports, Automotive Exports, Motor Vehicle Assembly, Motor Vehicle Market, Regional, Global

\section{Introduction}

The automotive sector is one of the largest sectors in terms of cross-border trade in the world. In this respect, it reflects the current economic situation of the world to a large extent. This study reports the world and regions' automotive imports and exports, motor vehicle assembly and market characteristics as well, while considering how the global automotive industry is evolved in relation to 2003. Therefore, this study does not only analyse supply and demand related economic characteristics of the global automotive sector, but it also examines cross-border economic relations of the sector. In addition, this study does not just consider one economy or a group of economies, it also considers the whole world as well as regions. Furthermore, this study examines developments in the global automotive sector in comparison with 2003. As a result, this study aims to provide insights into the global automotive sector and automotive sectors of regions by considering key economic indicators.

It is widely argued that Asian countries are rising in economic significance in the world [1] (please see Yerrabati and Hawkes [2] for a review of source of this economic performance). Thus, it is the main purpose of this study to investigate, this argument holds by focusing on main economic dynamics of one of the most significant sectors in the world, namely the global automotive sector over the last decade [3]. This study attempts to provide a better understanding of overall economic structures as well as trends in the world across regions.

There are fifteen highly large motor vehicle groups in the world accounting for about $82 \%$ of the world motor vehicle assembly. There are also around one hundred global mega suppliers in the world. These largest motor vehicle groups and global mega suppliers are head-quartered in Japan, Germany, the USA, Korea, France, Italy, China and Canada. Furthermore, there are growing trends in clustering, follow source and regionalisation in the automotive sector. On the other hand, despite implementation of widespread liberal economic policies around the world, governments still highly influence decision-making in the automotive sector via regulations, investment incentives and supports, monetary and fiscal policies [4].

Findings of this study are that first, despite a lower share in the global automotive sector compare to the last decade [5], Europe is still the largest automotive importer and exporter, and the second largest motor vehicle assembly region after Asia-Pacific in the world [6]. Europe is also the third largest motor vehicle market after Asia-Pacific and the Americas. Furthermore, Europe has the second largest motor vehicle fleet after the Americas and the highest motor vehicle ownership rate amongst regions in the world.

Second, on the other hand, Asia-Pacific has obtained a larger share in the world automotive imports and exports, motor vehicle assembly and market compared to the last decade [7]. Asia-Pacific is the third largest automotive importer after Europe and the Americas, and the second largest automotive exporter after Europe in the world. Asia-Pacific is the largest motor vehicle assembly region and market in the world. Along with Europe, Asia-Pacific is the only region that assembles more motor vehicles than its internal demand. Given Asia-Pacific's first place in the world motor vehicle assembly and market, but its second place in the world automotive exports and its third place 
in the world automotive imports, Asia-Pacific is less engaged in the international automotive trade than Europe and the Americas [8]. On the other hand, despite its recent high performance in the global automotive sector, Asia-Pacific still has the third largest motor vehicle fleet and the third highest motor vehicle ownership rate amongst regions in the world.

Third, the Americas have also had a lower share in the global automotive sector as in the case of Europe compared to the last decade [5]. The Americas are the second largest automotive importer after Europe and the third largest automotive exporter after Europe and Asia-Pacific in the world. The Americas are also the third largest motor vehicle assembly region after Asia-Pacific and Europe in the world [6]. On the other hand, the Americas are the second largest motor vehicle market after Asia in the world leading the Americas to assemble much fewer motor vehicles than their internal demand. Despite their relatively weaker performance in the global automotive sector during the last decade, the Americas still have the largest motor vehicle fleet and the second highest motor vehicle ownership rate after Europe in the world.

Given trends and rankings of the largest regions in the global automotive sector, variations in extent of intra-regional and inter-regional automotive trade across regions should be emphasised. Around two thirds of Europe and Americas' cross-border automotive trade are internal, whilst about one fifth of Asia-Pacific's cross-border automotive trade are internal [9]. Therefore, a higher share of cross-border automotive trade interactions of Europe and the Americas stated earlier tend to be within their own respective regions.

This study proceeds as follows: Section two introduces the global automotive sector, while providing historical background, main trends and government policies implemented. Section three explains how regional shifts in international automotive trade, motor vehicle assembly and market are investigated. Sections from four to seven thoroughly examine international trade, motor vehicle production, market and in use characteristics of the global automotive sector by regions and their transformations over the last decade. The last section discusses main findings of this study.

\section{Structure of the Global Automotive Sector}

Motor vehicles originated from Europe, specifically from Germany and France with the development of gasoline engine in the late $19^{\text {th }}$ century. Nevertheless, the USA dominated the world automotive industry due to its application of mass production techniques until the second half of the $20^{\text {th }}$ century. After this period, European countries and Japan also gained prominence in assembly and exports of motor vehicles [10-12]. Foreman-Peck [13], Casson [14], and Clark and Fujimoto [15] report transformations that this industry experienced throughout the second half of the $20^{\text {th }}$ century.

The global automotive sector consists of a large number of diverse parties. It embodies automotive parts suppliers, motor vehicle assemblers and consumers (buyers), dealers and distributors, after-market services, engineering firms, test centres, and interest groups including trade unions, business associations and lobbies. This sector also has extensive backward and forward linkages with other manufacturing industries e.g., steel and rubber, and service sectors, such as financial institutions and insurance companies. Therefore, the sector accounts for a substantial part of the economy.

The automotive industry includes passenger car and commercial vehicle assemblers; these enterprises assemble motor vehicles and produce particular automotive parts such as engines and transmissions. Motor vehicle assemblers are also involved in design, research and development (R\&D), test and marketing activities. In addition to assemblers, this industry incorporates automotive parts suppliers, which are segmented as 0.5 (global mega suppliers), $1^{\text {st }}, 2^{\text {nd }}$, and $3^{\text {rd }}$ tier suppliers. Each supplier in upstream serves one another, $3^{\text {rd }}$ tier suppliers serve $2^{\text {nd }}$ tier suppliers, in return $2^{\text {nd }}$ tier suppliers serve $1^{\text {st }}$ and 0.5 tier suppliers. Consequently, 0.5 and $1^{\text {st }}$ tier suppliers provide assemblers with systems or modules, subsystems, automotive parts of motor vehicles $[16,17]$.

The reason why 0.5 automotive parts suppliers are called global mega suppliers is that they are larger in terms of employment and turnover than particular motor vehicle assemblers and they are closer to assemblers than $1^{\text {st }}$ tier automotive parts suppliers [9]. Global mega suppliers or 0.5 tier suppliers are also called system suppliers. These suppliers widely engage in assembling parts provided by other automotive parts suppliers to form systems or modules and subsystems, such as compact full doors, brake systems, power trains for shipping them to motor vehicle assemblers. This trend on global mega suppliers, and hence reduction in number of automotive parts suppliers with which motor vehicle assemblers work is partly driven by the demand from motor vehicle assemblers to reduce their inventory and coordination costs and difficulties [18]. It should also be noted that particular mega suppliers are former subsidiaries of motor vehicle assemblers occurred due to restructuring in the industry resulting in vertical disintegration of assemblers.

Along with production of automotive parts and assembly of modules, global mega and $1^{\text {st }}$ tier suppliers also widely engage in design and $R \& D$ activities in close cooperation with motor vehicle assemblers called co-design. On the other hand, $2^{\text {nd }}$ and $3^{\text {rd }}$ automotive parts suppliers engage mostly in production activities based on specifications provided by global mega and $1^{\text {st }}$ tier 
suppliers, and motor vehicle assemblers. This close cooperation is mainly the result of efficiency seeking strategies of motor vehicle assemblers; therefore, motor vehicle assemblers have left engagement in low value-added processes and production of low value-added automotive parts to suppliers. Thus, motor vehicle assemblers are the leaders in organising the automotive supply chain.

There are fifteen highly large motor vehicle groups in the world. They vary in their share of the world motor vehicle assembly from about $2 \%$ to around $11 \%$. They all constitute about $82 \%$ of the world motor vehicle assembly - data is compiled by the International Organization of Motor Vehicle Manufacturers (OICA). There are five large groups head-quartered in Japan comprising $27.1 \%$ of the world motor vehicle assembly in 2015. There are three large groups head-quartered in Germany making up $15.9 \%$ of the world motor vehicle assembly, while there are two large groups head-quartered in the USA constituting $15.4 \%$ of the world motor vehicle assembly in 2015. There is one large group head-quartered in Korea making up $8.9 \%$ of the world motor vehicle assembly in 2015. There are two large groups head-quartered in France comprising $6.7 \%$ of the world motor vehicle assembly in 2015. There is one large group controlled by Italy and another large group head-quartered in China constituting $5.4 \%$ and $2.5 \%$ of the world motor vehicle assembly, respectively in 2015 . There are also around one hundred global mega suppliers in the world. In 2015, the largest fifteen global mega suppliers in terms of turnover are Robert Bosch head-quartered in Germany, Denso head-quartered in Japan, Magna International head-quartered in Canada, Continental head-quartered in Germany, ZF Friedrichshafen head-quartered in Germany, Hyundai Mobis head-quartered in Korea, Aisin Seiki head-quartered in Japan, Faurecia head-quartered in France, Johnson Controls head-quartered in the USA, Lear head-quartered in the USA, Valeo head-quartered in France, Delphi Automotive head-quartered in the USA, Yazaki head-quartered in Japan, Sumitomo Electric Industries head-quartered in Japan and JTEKT head-quartered in Japan, respectively [19]. As a result, locations of the headquarters of the largest fifteen motor vehicle assemblers are, to a large extent, in line with locations of the headquarters of the largest fifteenth global mega automotive parts suppliers.

There are three main trends worth pointing out here. First, there is an increasing trend towards clustering within a country or a region having two dimensions. The first dimension is that automotive parts suppliers producing heavy, bulky and model specific parts are located close to motor vehicle assembly plants for precise time delivery and reduction of transportation costs. The second dimension is that design centres are likely to cluster in large or well-established markets to satisfy local needs and tastes [4]. Second, when motor vehicle assemblers invest in or move to any location, they tend to take their supply base with themselves, which is called "follow source" [17, 20]. Ivarsson and Alvstam [20] argue that follow source trend is mostly driven by quality standards requirements and just in time delivery schemes of motor vehicle assemblers. This follow source might be in the form of green-field investments, joint ventures with local enterprises, or acquisition of local enterprises. This trend of follow source has resulted in governments and local governments generously providing investment incentives to motor vehicle assemblers to attract investments of automotive parts suppliers, as well. The last trend is regionalisation [9]. International automotive trade tends to be bounded by geography. This is mainly due to prevalence of trade areas and agreements between geographically close countries. Around two thirds of Europe and Americas' cross-border automotive trade are internal, whereas about one fifth of Asia-Pacific's cross-border automotive trade are internal [9].

Due to its scale and significance in the economy and its large backward and forward linkages with other sectors, governments pay special attention to the automotive sector. Therefore, this industry has been subject to heavy government interventions and regulations, and highly protectionist policies from voluntary export restrictions [21], quotas, high customs tariff, local content requirements [22], to obligations to form joint ventures with local enterprises [23]. However, mainly after 1990s especially in developed countries and to some extend in developing countries, this industry has been liberalized. Nevertheless, governments are still prominent in affecting decision-making processes in the automotive sector via regulations, investment incentives and supports, monetary and fiscal policies.

\section{Methodology and Data}

In order to identify regional dynamics of the global automotive sector, this study analyses key economic characteristics of the global automotive sector, namely international automotive trade and motor vehicle assembly and market patterns. In this regard, this study benefits from publicly available automotive sector data of official international institutions.

This study differs in its approach to the automotive sector from existing studies in four main ways. First, this study benefits from publicly available data of international automotive trade, and motor vehicle production and sales, while other automotive industry case studies are based on surveys and interviews with industry representatives, and factory, R\&D, production, purchase and supply managers, and industry specific reports $[4,20,24]$. Second, approach of this study can provide an overall picture of the automotive sector rather than description of individual country or region or a specific section of the automotive 
sector [25-29]. Therefore, this study can supply a more representative view of the global automotive sector. Third, this study does not just consider supply characteristics of the global automotive industry [4, 28, 30], but it also examines dynamics of motor vehicle demand in the world across regions. Therefore, this approach enables simultaneous assessment of supply and demand structures of the global automotive sector by regions. Fourth, this study does not just regard the motor vehicle section of the automotive industry [26, 31, 32], but it also considers automotive parts supply section of the automotive industry. This approach is to provide a complete account of the global automotive industry.

This study establishes a list of automotive parts and motor vehicles from three sources, namely Office of Transportation and Machinery U.S. Department of Commerce [33], Republic of Turkey Ministry of Economy [34] and European Commission [35] to compile relevant automotive data. After obtaining automotive lists from these three sources, this study thoroughly examines and harmonises these three lists to establish a comprehensive and accurate list of automotive parts and motor vehicles at 6-digit Harmonized System (HS) level.

International trade data is retrieved from the United Nations' (UN) publicly available International Trade Statistics Database (Comtrade) based on 6-digit automotive parts and motor vehicle HS codes accessed at https://comtrade.un.org/data/. The UN constructs this dataset by compiling international trade data reports of each individual country. On the other hand, motor vehicle assembly, sales and in use data is obtained from the OICA's database accessed at http://www.oica.net. The OICA compiles this dataset from reports of national trade organisations, OICA members or correspondents, National Offices of Statistics or Ministries of Transport.

\section{International Trade Characteristics of the Global Automotive Industry}

\subsection{Automotive Imports across Regions}

Table 1 reports that in 2015, the world automotive imports were more than $\$ 1.7$ trillion increased by around $86 \%$ compared to 2003 . In $2015,48.9 \%$ of these imports were in the form of motor vehicles decreased by $8.2 \%$ in comparison with 2003, while the remaining world automotive imports were in the form of automotive parts. In 2015, automotive imports constituted around $11 \%$ of world's total imports contracted by $10.2 \%$ in relation to 2003. In 2003, Europe constituted $51.3 \%$ of the world automotive imports being the largest automotive importer in the world, but its share in the world automotive imports decreased by $13.6 \%$ to $44.3 \%$, it was still the largest automotive importer in the world in 2015. On the other hand, in 2015 the Americas made up 34.5\% of the world automotive imports decreased by $2.6 \%$ in relation to 2003 , but they were still the second largest automotive importer in the world after Europe in 2015. In 2015, Asia-Pacific constituted $16.1 \%$ of the world automotive imports increased by $53.2 \%$ from $10.5 \%$ in 2003 giving rise Asia-Pacific to occupy the third place in the world automotive importer ranking after the Americas [5, 7, 8]. In 2015, the Middle East and North Africa (MENA) and Africa increased their shares in the automotive imports by $121.2 \%$ and $20.4 \%$ to $3.9 \%$ and $1.2 \%$, being placed the fourth and fifth largest automotive importers in the world, respectively.

Table 1. Automotive Imports across Regions (in current billion US dollars)

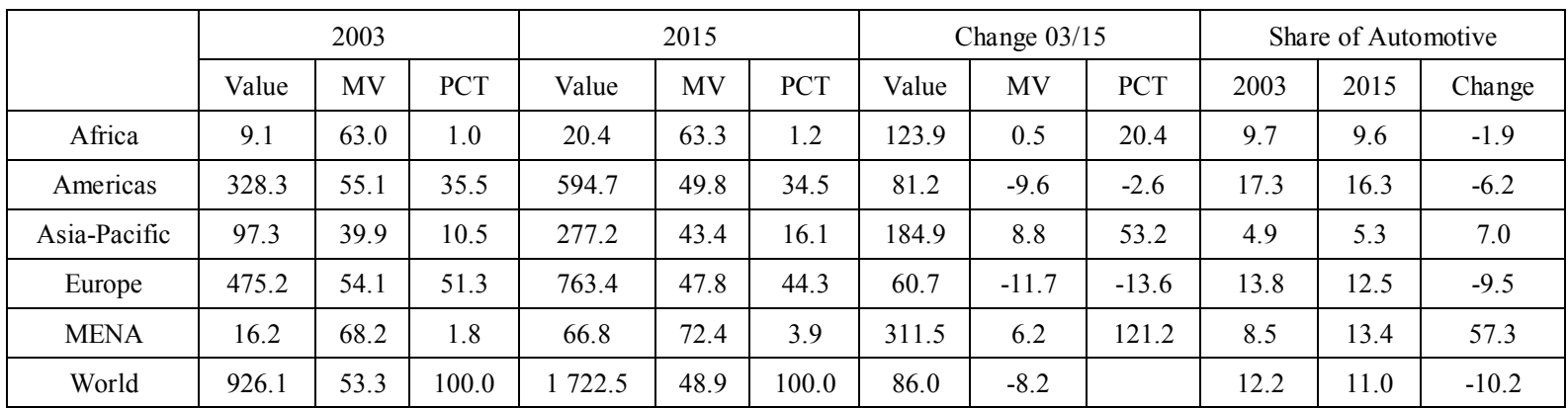

Notes: Data is based on reporting of each individual country. Shares are rounded, so they may not add up to $100 \%$. MV stands for motor vehicle. PCT means percent. 2015 data on Indonesia is unavailable, instead 2014 data is used for Indonesia. International trade data on Iran is unavailable for the specified years.

Source: Calculations are based on the UN Comtrade. 
Table 1 also reveals that in 2015, 72.4\% of MENA's automotive imports were in the form of motor vehicles up by $6.2 \%$ compared to 2003 placing the MENA at the top of the list in this particular ranking in the world. The MENA was followed by Africa, the Americas, Europe and Asia-Pacific, respectively and this order of ranking was identical in 2003, as well despite positive and negative changes in this particular share for regions between 2003 and 2015. In spite of having the largest increase in motor vehicles' share in automotive imports in comparison with 2003, Asia-Pacific was the region with the lowest share in 2015 as stated earlier $[5,7,8]$. Europe and the Americas were only regions that imported a larger share of their automotive imports in the form of automotive parts in 2015 compared with 2003 [6,9].

Furthermore, Table 1 indicates share of automotive imports in the total imports for regions. In 2015, $16.3 \%$ of total imports of the Americas were in the automotive industry down by $6.2 \%$ in comparison with 2003 still placing the Americas at the top of the list in this particular area in the world. The Americas were followed by the MENA, Europe, Africa and Asia-Pacific, respectively in 2015. Asia-Pacific had the lowest automotive imports share in the total imports almost half of the closest region $[5,7,8]$. All regions' automotive imports shares in their total imports decreased in 2015 compared to 2003 except the MENA and Asia-Pacific that increased their automotive imports shares in total imports by $57.3 \%$ and $7 \%$, respectively. As a result, the Americas and Europe were only regions whose automotive imports shares in total imports were larger than $10 \%$ in both 2003 and 2015 . Nevertheless, due to larger relative increase in automotive imports, the MENA was also one of the regions in addition to the Americas and Europe with a share of automotive imports in the total imports exceeding $10 \%$.

\subsection{Motor Vehicle Imports across Regions}

Table 2 presents that in 2015, around 41.9 million units of motor vehicles were imported worldwide increased by just more than a quarter from around 33.3 million units in
2003. Europe, in 2003 constituted $57.6 \%$ of the world motor vehicle imports being the largest motor vehicle importer in the world in line with Table 1, but Europe gained more prominence in the case of the motor vehicle imports compared to the automotive imports. One of the reasons for these high units of motor vehicle imports by Europe was the practice of importing motor vehicles to export. On the other side, Europe's share in world motor vehicle imports decreased by $16.7 \%$ to $47.9 \%$, but it was still the largest motor vehicle importer in the world in 2015. The Americas were the second largest motor vehicle importer in the world in 2015, which is parallel to automotive imports ranking by making up $33 \%$ of the world motor vehicle imports up by $7.4 \%$ from $30.7 \%$ in 2003. Asia-Pacific, in 2003 constituted $8.6 \%$ of the world motor vehicle imports, but it made up $12.5 \%$ of the world motor vehicle imports up by $45.1 \%$ in 2015 leading Asia-Pacific to be the third largest motor vehicle importer in the world consistent with its place in the world automotive imports. Nevertheless, Asia-Pacific's share in the world motor vehicle imports was lower than its share in the world automotive imports since Asia-Pacific relatively imported a larger share of its automotive imports in the form of automotive parts rather than motor vehicles and other regions comparatively imported more of their automotive products in the form of motor vehicles despite tendency of Asia-Pacific towards importing more automotive products as motor vehicles in 2015 [5, 7, 8]. The MENA, in 2015 more than doubled its share in the world motor vehicle imports to $5.7 \%$ from $2.4 \%$ in 2003 having the largest increase in motor vehicle imports amongst regions. MENA's share in the world motor vehicle imports exceeded its share in the world automotive imports as the MENA made the majority of its automotive imports in the form of motor vehicles as reported in Table 1. Africa had the lowest share in the world motor vehicle imports in both 2003 and 2015 by making up $0.7 \%$ and $0.9 \%$ of the world motor vehicle imports, respectively that meant an increase of $39.3 \%$ in its share in the world motor vehicle imports between 2003 and 2015.

Table 2. Motor Vehicle Imports across Regions (in thousand units)

\begin{tabular}{|c|c|c|c|c|c|c|}
\hline & \multicolumn{2}{|c|}{2003} & \multicolumn{2}{|c|}{2015} & \multicolumn{2}{|c|}{ Change $03 / 15$} \\
\hline & QTY & PCT & QTY & PCT & QTY & PCT \\
\hline Africa & 224.0 & 0.7 & 392.4 & 0.9 & 75.2 & 39.3 \\
\hline Americas & 10250.2 & 30.7 & 13839.4 & 33.0 & 35.0 & 7.4 \\
\hline Asia-Pacific & 2869.5 & 8.6 & 5234.4 & 12.5 & 82.4 & 45.1 \\
\hline Europe & 19192.0 & 57.6 & 20101.5 & 47.9 & 4.7 & -16.7 \\
\hline MENA & 812.6 & 2.4 & 2371.6 & 5.7 & 191.9 & 132.1 \\
\hline World & 33348.2 & 100.0 & 41939.3 & 100.0 & 25.8 & \\
\hline
\end{tabular}

Notes: Data is based on reporting of each individual country. Data includes passenger cars, commercial vehicles and farm tractors. Shares are rounded, so they may not add up to $100 \%$. QTY stands for quantity. PCT means percent. 2015 data on Indonesia is unavailable, instead 2014 data is used for Indonesia. In case of missing or erroneous data, closest year's data with consistent entry is used. Data on Africa is not reliable since volume unit of trade is mixed with weight unit of trade. International trade data on Iran is unavailable for the specified years.

Source: Calculations are based on the UN Comtrade. 


\subsection{Automotive Exports across Regions}

Table 3 presents that in 2015, the world automotive exports were more than $\$ 1.7$ trillion increased by $90.1 \%$ compared to 2003. This rise in the world automotive exports was smaller than the rise in the world exports. In $2015,49.3 \%$ of these exports were in the form of motor vehicles decreased by $7.7 \%$ in comparison with 2003 , while the remaining automotive exports were in the form of automotive parts. In 2015, automotive exports constituted around $11.2 \%$ of the world exports contracted by $10.4 \%$ in relation to 2003 . One should consult the second paragraph of section 3.4. for explanation of the discrepancy between the total values of automotive exports and imports.

In 2003, Europe constituted $54.8 \%$ of the world automotive exports being the largest automotive exporter in the world, but its share in the world automotive exports decreased by $9.2 \%$ to $49.8 \%$ in 2015 still a larger share compared to Europe's share in the world exports. In 2015, Europe's share in the world automotive exports was 5.5 percentage points larger than its share in the world automotive imports. In 2015, Asia-Pacific made up 26.8\% of the world automotive exports up by $23.2 \%$ from $21.7 \%$ in 2003 being the second largest automotive exporter in the world overtaking the place of the Americas. Asia-Pacific's share in the world exports was larger than its share in the world automotive exports in both 2003 and 2015. Asia-Pacific's share in the world automotive exports was more than 10 percentage points larger than its share in the world automotive imports in both 2003 and 2015. In 2015 the Americas constituted $22.3 \%$ of the world automotive exports down by $1.8 \%$ from $22.7 \%$ in 2003 losing their second place in the ranking of the share in the world automotive exports in 2003 to Asia-Pacific and occupying the third place in 2015. Americas' share in the world exports were more than 4 percentage points smaller than their share in the world automotive exports in both 2003 and 2015. On the other hand, Americas' share in the world automotive exports were more than 12 percentage points smaller than their share in the world automotive imports in both 2003 and 2015 [6, 9]. Despite constituting more than $3 \%$ of the world exports and being the fourth largest exporter in the world in both 2003 and 2015, the MENA was overtaken by Africa when MENA's share in the world automotive exports was considered in 2003 and 2015. The MENA made up $0.5 \%$ of the world automotive exports increased by $356.1 \%$ from $0.1 \%$ in 2003 occupying the last place in the share of the world automotive exports in 2015. This was the largest increase amongst regions', but it was still short of Africa's share in the world automotive exports. MENA's share in the world automotive imports outstripped its share in the world automotive exports by a large margin in both 2003 and 2015. Africa constituted around $0.6 \%$ of the world automotive exports with a positive change of $0.3 \%$ between 2003 and 2015 being in the fourth place in the ranking of the share in the world automotive exports in both 2003 and 2015. Africa's share in the world exports was well above its share in the world automotive exports in both 2003 and 2015. Africa's share in the world automotive imports also exceeded its share in the world automotive exports in both 2003 and 2015.

Table 3 also indicates that in 2015, regions conducted more than half of their automotive exports in the form of motor vehicles except Asia-Pacific. In 2015, 68.6\% of Africa's automotive exports were in the form of motor vehicles being the first region in this particular ranking followed by the MENA, Europe, the Americas and Asia-Pacific, respectively. Asia-Pacific and Europe were only regions whose shares of motor vehicles in the automotive exports decreased by $21.4 \%$ and $5.9 \%$, respectively. This decrease only led Asia-Pacific to dispatch less than $50 \%$ of its automotive exports in the form of motor vehicles in 2015. In addition to this, Asia-Pacific also conducted less than $50 \%$ of its automotive imports in the form of motor vehicles as reported in Table 1. Asia-Pacific and the MENA were only regions whose shares of motor vehicles in the automotive imports exceeded their corresponding shares of motor vehicles in the automotive exports in 2015.

Table 3. Automotive Exports across Regions (in current billion US dollars)

\begin{tabular}{|c|c|c|c|c|c|c|c|c|c|c|c|c|}
\hline & \multicolumn{3}{|c|}{2003} & \multicolumn{3}{|c|}{2015} & \multicolumn{3}{|c|}{ Change $03 / 15$} & \multicolumn{3}{|c|}{ Share of Automotive } \\
\hline & Value & MV & PCT & Value & MV & PCT & Value & MV & $\mathrm{PCT}$ & 2003 & 2015 & Change \\
\hline Africa & 5.8 & 52.1 & 0.6 & 11.0 & 68.6 & 0.6 & 90.6 & 31.7 & 0.3 & 6.6 & 6.9 & 4.6 \\
\hline Americas & 209.7 & 48.5 & 22.7 & 391.5 & 51.1 & 22.3 & 86.7 & 5.2 & -1.8 & 15.3 & 14.2 & -7.1 \\
\hline Asia-Pacific & 201.0 & 52.6 & 21.7 & 470.8 & 41.3 & 26.8 & 134.2 & -21.4 & 23.2 & 9.4 & 8.1 & -13.9 \\
\hline Europe & 507.3 & 55.8 & 54.8 & 875.3 & 52.5 & 49.8 & 72.5 & -5.9 & -9.2 & 14.5 & 13.7 & -5.3 \\
\hline MENA & 1.1 & 38.4 & 0.1 & 9.5 & 59.2 & 0.5 & 767.0 & 54.1 & 356.1 & 0.4 & 1.8 & 340.6 \\
\hline World & 924.8 & 53.4 & 100.0 & 1758.0 & 49.3 & 100.0 & 90.1 & -7.7 & & 12.5 & 11.2 & -10.4 \\
\hline
\end{tabular}

Notes: Please see notes of Table 1.

Source: Calculations are based on the UN Comtrade. 
Furthermore, Table 3 reveals share of automotive exports in the total exports for regions. In 2015, 14.2\% of total exports of the Americas were in the automotive industry down by $7.1 \%$ in comparison with 2003 still placing the Americas at the top of the list in this particular area in the world. The Americas were followed by Europe, Asia-Pacific, Africa and the MENA, respectively in both 2003 and 2015. Compared with the order of rankings of shares of automotive imports in the total imports, the order of rankings of shares of automotive exports in the total exports changed in 2003 and 2015. The MENA had the second largest automotive imports share in the total imports as reported in Table 1, but it had the lowest automotive exports share in the total exports in 2015. Asia-Pacific had the lowest automotive imports share in the total imports, while it had the third largest automotive exports share in the total exports in both 2003 and 2015 [5, $7,8]$. All regions' automotive exports shares in the total exports decreased in 2015 compared to 2003 except the MENA and Africa that increased their automotive exports shares in the total exports by $340.6 \%$ and $4.6 \%$, respectively. As a result, the Americas and Europe were only regions whose automotive exports shares in the total exports were larger than $10 \%$ in both 2003 and 2015. This was also valid for corresponding automotive imports share for both 2003 and 2015. One should note that the MENA increased its share of automotive imports in the total imports to $13.4 \%$ in 2015. Tables 1 and 3 also indicate that in both 2003 and 2015, shares of automotive exports in the total exports of Asia-Pacific and Europe exceeded their corresponding automotive imports shares in the total imports, while shares of automotive imports in the total imports of Africa, the Americas and MENA outstripped their corresponding automotive imports shares in the total imports.

\subsection{Motor Vehicle Exports across Regions}

Table 4 reports that in 2015, about 47.9 million units of motor vehicles were exported worldwide increased by about 30\% from around 36.9 million units in 2003 .

One should note that total number of motor vehicles exported in the world in Table 4 is larger than total number of motor vehicles imported in the world in Table 2. The main reason for this discrepancy is that in particular instances unfinished motor vehicles are usually declared by exporters as finished motor vehicles to origin countries, while they are declared by importers to destination countries as importation of other items to be assembled. This practice enables importers to avoid bearing high customs tariffs of motor vehicles and pay low customs tariffs of other items. This is also reflected in the total values of automotive exports in Table 3 and imports in Table 1.

Europe, in 2003 constituted $59.2 \%$ of the world motor vehicle exports being the largest motor vehicle exporter in the world in line with Table 3, but Europe had more significance in the case of the motor vehicle exports compared to the automotive exports. One of the reasons for these high units of motor vehicle exports by Europe was the practice of exporting initially imported motor vehicles as underlined in section 3.2. On the other hand, Europe's share in the world motor vehicle exports decreased by $12.6 \%$ to $51.7 \%$, but it was still the largest motor vehicle exporter in the world in 2015. Europe's share in the world motor vehicle exports was also about 4 percentage points larger than its share in the world motor vehicle imports in 2015 [6,9]. Asia-Pacific, in 2015 made up $28 \%$ of the world motor vehicle exports increased by $22.6 \%$ from $22.8 \%$ in 2003 leading Asia-Pacific to be the second largest motor vehicle exporter in the world consistent with its place in the world automotive exports, but with a higher share in the world motor vehicle exports. Asia-Pacific's share in the world motor vehicle exports was also around 15 percentage points larger than its share in the world motor vehicle imports in both 2003 and 2015. This positive differential was the largest amongst regions in both 2003 and 2015 [5, 7, 8]. The Americas, in 2015 constituted $19 \%$ of the world motor vehicle exports increased by $11.2 \%$ from $17.1 \%$ in 2003 resulting in the Americas being the third largest motor vehicle exporter in the world consistent with their place in the world automotive exports. On the other hand, share of automotive exports of the Americas in the world automotive exports were well larger than share of motor vehicle exports of the Americas in the world motor vehicle exports in both 2003 and 2015. This was due mainly to the fact that unit value of motor vehicles exported by countries in the Americas was much larger than Asia-Pacific's in both 2003 and 2015. Americas' share in the world motor vehicle exports were also about 14 percentage points smaller than their share in the world motor vehicle imports in both 2003 and 2015. This negative differential was the largest amongst regions in both 2003 and 2015 [6,9]. Africa in 2015 made up 0.7\% of the world motor vehicle exports down by $12.3 \%$ from $0.8 \%$ in 2003 leading Africa to be the fourth largest motor vehicle exporter in the world consistent with its place in the world automotive exports. Despite changes of various magnitudes, Africa's share in the world motor vehicle exports was not highly different from its share in the world motor vehicle imports in both 2003 and 2015. The MENA, in 2015 constituted $0.5 \%$ of the world motor vehicle exports increased by more than 5.5 times from $0.1 \%$ in 2003 still placing the MENA to the last spot amongst the world motor vehicle exporters in line with its place in the world automotive exports. MENA's share in the world motor vehicle exports was smaller than its share in the world motor vehicle imports in both 2003 and 2015 and even the gap widened in 2015 , despite having the largest increase in the world motor vehicle exports share. 
Table 4. Motor Vehicle Exports across Regions (in thousand units)

\begin{tabular}{|c|c|c|c|c|c|c|}
\hline & \multicolumn{2}{|c|}{2003} & \multicolumn{2}{|c|}{2015} & \multicolumn{2}{|c|}{ Change $03 / 15$} \\
\hline & QTY & PCT & QTY & PCT & QTY & PCT \\
\hline Africa & 292.9 & 0.8 & 332.9 & 0.7 & 13.7 & -12.3 \\
\hline Americas & 6319.2 & 17.1 & 9116.6 & 19.0 & 44.3 & 11.2 \\
\hline Asia-Pacific & 8429.0 & 22.8 & 13402.3 & 28.0 & 59.0 & 22.6 \\
\hline Europe & 21834.3 & 59.2 & 24750.1 & 51.7 & 13.4 & -12.6 \\
\hline MENA & 30.6 & 0.1 & 259.2 & 0.5 & 746.3 & 552.6 \\
\hline World & 36906.0 & 100.0 & 47861.0 & 100.0 & 29.7 & \\
\hline
\end{tabular}

Notes: Please see notes of Table 2.

Source: Calculations are based on the UN Comtrade.

Table 5. Motor Vehicle Assembly across Regions (in thousand units)

\begin{tabular}{|c|c|c|c|c|c|c|c|c|c|c|c|c|}
\hline & \multicolumn{3}{|c|}{2003} & \multicolumn{3}{|c|}{2015} & \multicolumn{3}{|c|}{ Change $03 / 15$} & \multicolumn{3}{|c|}{ Share of Export } \\
\hline & QTY & $\mathrm{PC}$ & PCT & QTY & $\mathrm{PC}$ & PCT & QTY & $\mathrm{PC}$ & PCT & 2003 & 2015 & Change \\
\hline Africa & 430.7 & 69.3 & 0.7 & 615.7 & 55.4 & 0.7 & 42.9 & -20.0 & -4.2 & 68.0 & 54.1 & -20.5 \\
\hline Americas & 18280.3 & 45.2 & 29.8 & 21013.4 & 44.9 & 23.0 & 15.0 & -0.7 & $\begin{array}{c}-23 . \\
0\end{array}$ & 34.6 & 43.4 & 25.5 \\
\hline Asia-Pacific & 21451.1 & 73.3 & 35.0 & 47209.2 & 83.8 & 51.6 & $\begin{array}{c}120 . \\
1 \\
\end{array}$ & 14.3 & 47.5 & 39.3 & 28.4 & -27.8 \\
\hline Europe & 20501.9 & 86.5 & 33.4 & 21331.5 & 87.1 & 23.3 & 4.0 & 0.7 & $\begin{array}{c}-30 \\
3\end{array}$ & 106.5 & 116.0 & 8.9 \\
\hline MENA & 651.9 & 86.1 & 1.1 & 1327.2 & 88.7 & 1.5 & $\begin{array}{c}103 . \\
6\end{array}$ & 3.0 & 36.4 & 4.7 & 19.5 & 315.7 \\
\hline World & 61315.9 & 69.5 & 100.0 & 91496.9 & 75.5 & 100.0 & 49.2 & 8.7 & & 60.2 & 52.3 & -13.1 \\
\hline
\end{tabular}

Notes: Data is based on reporting of each national motor vehicle assemblers association and estimates of the OICA. Data does not include farm tractors. 2015 Data on the Netherlands is obtained from the European Automobile Manufacturers' Association (ACEA). Shares are rounded, so they may not add up to $100 \%$. QTY means quantity. PC stands for passenger car. PCT means percent.

Source: Calculations are based on the OICA and ACEA's datasets, and UN Comtrade.

\section{Motor Vehicle Assembly across Regions}

When interpreting Table 5, one should note that while import and export data include farm tractors, assembly data does not include farm tractors, so assembly data on motor vehicles consists of data on assembly of passenger cars and commercial vehicles. There can also be double counting in the assembly data as indicated by the OICA. In addition to this, share of motor vehicle assembly exported for specific countries and, in particular, almost all European countries was larger than $100 \%$ in both 2003 and 2015. There are several reasons for this discrepancy. First, international trade data includes cross-border trade of farm tractors, while assembly data reported in Table 5 does not embody manufacture of farm tractors. Second, motor vehicles assembled in Europe and destined for export markets can be reported by more than one country i.e. both home-country of motor vehicle assembler and the country where motor vehicles are assembled, so there can be double counting of motor vehicle exports. Third, motor vehicles in inventory can be exported in a successive year, which creates lags, and hence discrepancies between timings of the assembly and exports of motor vehicles. Fourth, particular countries, especially European ones import high units of motor vehicles for export even if they do not add any value to imported motor vehicles, which deflates both import and export values as well as quantities. This practice was underlined in Tables 2 and 4. Fifth, export data of motor vehicles includes both newly assembled motor vehicles and second-hand motor vehicles that results in discrepancies between current assembly and export data of motor vehicles. Second-hand motor vehicle trades are very large amongst European countries as well as between European countries and other countries, so the discrepancy between current assembly and export data of motor vehicles is much larger for European countries.

Table 5 presents that in 2015, about 91.5 million units of motor vehicles were assembled worldwide increased by $49.2 \%$ from around 61.3 million units in 2003. In 2015, $75.5 \%$ of motor vehicles assembled worldwide were passenger cars up by $8.7 \%$ from $69.5 \%$ in 2003 , while the remaining were commercial vehicles. In 2015, 51.6\% of the world motor vehicle assembly were carried out by Asia-Pacific increased by $47.5 \%$ the largest increase amongst regions from 35\% in 2003 leading Asia-Pacific to be the largest motor vehicle assembling region in the world in both 2003 and 2015 [36, 37]. 83.8\% of motor vehicle assembly of Asia-Pacific, in 2015 were passenger cars up by $14.3 \%$ the largest increase amongst regions from $73.3 \%$ in 2003 a larger share than Africa and Americas'. In 2015, Europe made up 23.3\% of the world 
motor vehicle assembly decreased by $30.3 \%$ the largest fall amongst regions from $33.4 \%$ in 2003 . Europe's share was still larger than Americas' by a small margin leading Europe to be the second largest motor vehicle assembling region in the world in both 2003 and 2015. 87.1\% of motor vehicle assembly of Europe, in 2015 were passenger cars up by $0.7 \%$ a smaller increase from $86.5 \%$ in 2003 leading Europe to lose its first place in 2003 to the MENA. The Americas, in 2015 constituted 23\% of the world motor vehicle assembly decreased by $23 \%$ the second largest fall after Europe's amongst regions from $29.8 \%$ in 2003 still leading the Americas to be the third largest motor vehicle assembling region in the world in both 2003 and 2015. The Americas were the only region with more than $50 \%$ of their motor vehicle assembly were in the form of commercial vehicles due to high demands for commercial vehicles in the Americas, especially by the USA and Canada. Therefore, the Americas were the region with the lowest passenger car assembly share amongst regions in both 2003 and 2015. The MENA, in 2015 made up $1.5 \%$ of the world motor vehicle assembly up by $36.4 \%$ the second largest increase after Asia-Pacific's amongst regions from $1.1 \%$ in 2003 still leading the MENA to be the fourth largest motor vehicle assembling region in the world in both 2003 and 2015. $88.7 \%$ of motor vehicle assembly of the MENA, in 2015 were passenger cars up by $3 \%$ the second largest increase after Asia-Pacific's amongst regions from $86.1 \%$ in 2003 leading the MENA to gain the first place of Europe in 2003. Africa, in 2015 constituted around $0.7 \%$ of the world motor vehicle assembly decreased by $4.2 \%$ the smallest decrease amongst regions from about $0.7 \%$ in 2003 placing Africa in the last spot in the world in both 2003 and 2015. 55.4\% of motor vehicle assembly of Africa in 2015 were passenger cars decreased by $20 \%$ the largest fall amongst regions from $69.3 \%$ in 2003 still leading Africa to occupy the fourth spot before the Americas. Therefore, more than $50 \%$ of motor vehicle assembly of Africa were in the form of passenger cars in 2015.

Table 5 also reports share of motor vehicle exports in motor vehicle assembly across regions in 2003 and 2015 and percent change in this share between 2003 and 2015. $52.3 \%$ of the world motor vehicles assembled were exported, in 2015 decreased by $13.1 \%$ from $60.2 \%$ in 2003. Europe was the most motor vehicle export intensive region in the world in both 2003 and 2015, but these shares should be interpreted with caution as its motor vehicle exports was larger than its motor vehicle assembly in both 2003 and 2015 - the first paragraph of this section explains the reasons for these excessive motor vehicle exports. Africa, in 2015 exported $54.1 \%$ of its assembled motor vehicles decreased by $20.5 \%$ the second largest fall after Asia-Pacific's amongst regions from 68\% in 2003 still leading Africa to be the second largest motor vehicle export intensive region in the world in both 2003 and
2015. $43.4 \%$ of Americas' motor vehicle assembly were exported in 2015 increased by $25.5 \%$ the second largest increase after MENA's amongst regions from $34.6 \%$ in 2003 leading the Americas to be the third largest motor vehicle export intensive region in the world in 2015 by resulting in the Americas overtaking the third place of Asia-Pacific in 2003. In 2015, Asia-Pacific exported $28.4 \%$ of its assembled motor vehicles decreased by $27.8 \%$ the largest fall amongst regions from $39.3 \%$ in 2003 leading Asia-Pacific to be the fourth largest motor vehicle export intensive region in the world in 2015, resulting in Asia-Pacific losing its third place to the Americas in 2003. $19.5 \%$ of motor vehicle assembly of the MENA were exported in 2015 increased by more than threefold the largest increase amongst regions from 4.7\% in 2003, but still leading the MENA to occupy the last spot in the world in 2015.

\section{Motor Vehicle Sales across Regions}

When interpreting Table 6, one should note that 2003 motor vehicle sales data is unavailable, instead 2005 motor vehicle sales data is used. In addition to this, while import and export data include farm tractors, sales data does not include farm tractors, so sales data on motor vehicles consists of data on sales of passenger cars and commercial vehicles. Furthermore, share of motor vehicle sales imported for specific countries and, in particular, almost all European countries ware larger than $100 \%$ in both 2005 and 2015 . The first paragraph of section 4 explains the reasons for this discrepancy.

Table 6 presents that in 2015, motor vehicle sales worldwide were about 89.2 million units increased by $35.2 \%$ from around 65.9 million units in $2005.73 .8 \%$ of motor vehicle sales worldwide, in 2015 were passenger cars up by $7.5 \%$ from $68.6 \%$ in 2005 , while the remaining were commercial vehicles. In $2015,45 \%$ of the world motor vehicle sales were carried out by Asia-Pacific increased by $63.4 \%$ the largest increase amongst regions from $27.6 \%$ in 2005 leading Asia-Pacific to be the largest motor vehicle market in the world, resulting in Asia-Pacific overtaking the first place of the Americas in 2005 and moving up by two places [38]. $82 \%$ of motor vehicle sales of Asia-Pacific, in 2015 were passenger cars up by $13.1 \%$ the largest increase amongst regions from $72.5 \%$ in 2005 still the second largest share leading Asia-Pacific to overtake the second place of the MENA in 2005, but still highly close to MENA's share in 2015. The Americas, in 2015 constituted $28.3 \%$ of the world motor vehicle market decreased by $20.1 \%$ the third largest fall after Europe and Africa's amongst regions from $35.4 \%$ in 2005 still leading the Americas to be the second largest motor vehicle market in the world in 2015 losing their first place to Asia-Pacific in 2005. The Americas were the only region with around $50 \%$ of their motor vehicle sales 
were in the form of commercial vehicles due to high demands for such vehicles in the Americas, especially by the USA and Canada. Therefore, the Americas were the region with the lowest passenger car sales share amongst regions in both 2005 and 2015. In 2015, Europe made up $21.6 \%$ of the world motor vehicle market decreased by $32.7 \%$ the largest fall amongst regions from $32.2 \%$ in 2005 leading Europe to be the third largest motor vehicle market in the world in 2015 losing its second place to the Americas in 2005. 86.4\% of motor vehicle sales of Europe, in 2015 were passenger cars increased by $1.6 \%$ a small increase from $85 \%$ in 2005 still leading Europe to have the largest share in both 2005 and 2015. The MENA, in 2015 made up $4.2 \%$ of the world motor vehicle market up by $11.1 \%$ the second largest increase after Asia-Pacific's amongst regions from $3.7 \%$ in 2005 still leading the MENA to be the fourth largest motor vehicle market in the world in both 2005 and 2015. 81.9\% of motor vehicle sales of the MENA, in 2015 were passenger cars up by $5.7 \%$ the second largest increase after Asia-Pacific's amongst regions from $77.4 \%$ in 2005 having the third largest share but losing its second place to Asia-Pacific in 2005. On the other hand, it was still highly close to Asia-Pacific's share in 2015. Africa, in 2015 constituted around $0.9 \%$ of the world motor vehicle market decreased by $22.3 \%$ the second largest fall after Europe's from about 1.2\% in 2005 resulting in Africa being the smallest motor vehicle market in the world in both 2005 and $2015.67 \%$ of motor vehicle sales of Africa, in 2015 were passenger cars decreased by $0.5 \%$ a small and only fall amongst regions from $67.4 \%$ in 2005 still leading Africa to occupy the fourth spot before the Americas.

Table 6 also reports share of motor vehicle imports in motor vehicle sales across regions in 2005 and 2015 and change in this share between 2005 and $2015.47 \%$ of the motor vehicle sales worldwide were imported in 2015 decreased by $19.5 \%$ from $58.4 \%$ in 2005 . Europe was the most motor vehicle import intensive region in the world in both 2005 and 2015, but these shares should be interpreted with caution as Europe's motor vehicle imports was larger than its motor vehicle sales in both 2005 and 2015 - the second paragraph of section 3.4. explains the reasons for these excessive motor vehicle imports. $63.9 \%$ of motor vehicle sales of the MENA were imported in 2015 decreased by $5.4 \%$ the second largest fall after Asia-Pacific's amongst regions from $67.5 \%$ in 2005 , but still resulting in the MENA being the second largest motor vehicle import intensive region in the world in both 2005 and 2015. 54.8\% of Americas' motor vehicle sales were imported in 2015 increased by $8.9 \%$ the largest increase amongst regions from $50.4 \%$ in 2005 still leading the Americas to be the third largest motor vehicle import intensive region in the world in both 2005 and 2015 $49.1 \%$ of motor vehicle sales of Africa were imported in 2015 increased by $8.2 \%$ the second largest increase after Americas' amongst regions from $45.4 \%$ in 2005 leading Africa to be the fourth largest motor vehicle import intensive region in the world in both 2005 and 2015. 13\% of motor vehicle sales of Asia-Pacific were imported in 2015 decreased by $31.1 \%$ the largest fall amongst regions from $18.9 \%$ in 2005 resulting in Asia-Pacific being the least motor vehicle import intensive region in the world in both 2005 and 2015.

Furthermore, Table 6 presents that in 2015 the world motor vehicle sales were $2.5 \%$ smaller than the world motor vehicle assembly, whereas they were $2 \%$ smaller in 2005. MENA's motor vehicle sales, in 2015 was about 1.8 times larger than its motor vehicle assembly also valid for 2005 that was the largest positive difference amongst regions. Africa's motor vehicle sales, in 2015 was $29.7 \%$ larger than its motor vehicle assembly, whilst it was 42.3\% larger in 2005. Americas' motor vehicle sales, in 2015 were around $20 \%$ larger than their motor vehicle assembly also valid for 2005. Europe's motor vehicle sales, in 2015 was $9.5 \%$ smaller than its motor vehicle assembly, whereas it was $0.4 \%$ smaller in 2005 . Asia-Pacific's motor vehicle sales, in 2015 was $15 \%$ smaller than its motor vehicle assembly, whilst it was $27.9 \%$ smaller in 2005 that was the largest negative difference amongst regions. As a result, Asia-Pacific and Europe were only regions whose motor vehicle assembly were larger than their motor vehicle sales, whereas the MENA, Africa and the Americas were only regions whose motor vehicle assembly were smaller than their motor vehicle sales in both 2005 and 2015. 
Table 6. Motor Vehicle Sales across Regions (in thousand units)

\begin{tabular}{|c|c|c|c|c|c|c|c|c|c|c|c|c|c|c|c|}
\hline & \multicolumn{3}{|c|}{2005} & \multicolumn{3}{|c|}{2015} & \multicolumn{3}{|c|}{ Change $05 / 15$} & \multicolumn{3}{|c|}{ Share of Import } & \multicolumn{3}{|c|}{ Sales in relation to Assembly } \\
\hline & QTY & $\mathrm{PC}$ & PCT & QTY & $\mathrm{PC}$ & PCT & QTY & $\mathrm{PC}$ & PCT & 2005 & 2015 & Change & 2005 & 2015 & Change \\
\hline Africa & 759.8 & 67.4 & 1.2 & 798.6 & 67.0 & 0.9 & 5.1 & -0.5 & -22.3 & 45.4 & 49.1 & 8.2 & 42.3 & 29.7 & -29.7 \\
\hline Americas & 23335.5 & 49.8 & 35.4 & 25231.9 & 50.2 & 28.3 & 8.1 & 0.7 & -20.1 & 50.4 & 54.8 & 8.9 & 20.8 & 20.1 & -3.3 \\
\hline Asia-Pacific & 18165.3 & 72.5 & 27.6 & 40135.8 & 82.0 & 45.0 & 120.9 & 13.1 & 63.4 & 18.9 & 13.0 & -31.1 & -27.9 & -15.0 & -46.3 \\
\hline Europe & 21205.2 & 85.0 & 32.2 & 19298.4 & 86.4 & 21.6 & -9.0 & 1.6 & -32.7 & 100.6 & 104.2 & 3.5 & -0.4 & -9.5 & 2046.9 \\
\hline MENA & 2468.9 & 77.4 & 3.7 & 3710.3 & 81.9 & 4.2 & 50.3 & 5.7 & 11.1 & 67.5 & 63.9 & -5.4 & 173.9 & 179.6 & 3.2 \\
\hline World & 65934.7 & 68.6 & 100.0 & 89175.1 & 73.8 & 100.0 & 35.2 & 7.5 & & 58.4 & 47.0 & -19.5 & -2.0 & -2.5 & 30.1 \\
\hline
\end{tabular}

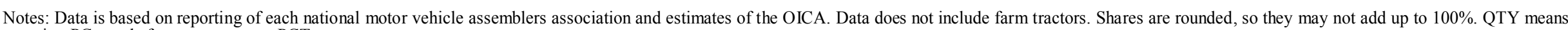
quantity. PC stands for passenger car. PCT means percent.

Source: Calculations are based on the OICA's dataset and UN Comtrade. 
Table 7. Motor Vehicle in Use across Regions (in million units)

\begin{tabular}{|c|c|c|c|c|c|c|c|c|c|c|}
\hline & \multicolumn{3}{|c|}{2005} & \multicolumn{3}{|c|}{2014} & \multicolumn{3}{|c|}{ Change $05 / 14$} & \multirow{2}{*}{$\begin{array}{l}\text { Motorisation } \\
\text { Rate (2014) }\end{array}$} \\
\hline & QTY & $\mathrm{PC}$ & PCT & QTY & $\mathrm{PC}$ & PCT & QTY & $\mathrm{PC}$ & PCT & \\
\hline Africa & 15.4 & 63.6 & 1.7 & 24.7 & 66.0 & 2.0 & 60.8 & 3.9 & 16.1 & 114.2 \\
\hline Americas & 327.9 & 61.6 & 36.7 & 403.8 & 57.3 & 32.7 & 23.2 & -6.9 & -11.1 & 350.6 \\
\hline Asia-Pacific & 193.8 & 72.6 & 21.7 & 366.4 & 78.3 & 29.6 & 89.1 & 7.8 & 36.5 & 266.6 \\
\hline Europe & 323.5 & 85.9 & 36.2 & 384.2 & 85.8 & 31.1 & 18.7 & -0.1 & -14.3 & 495.9 \\
\hline MENA & 32.2 & 72.0 & 3.6 & 57.2 & 74.5 & 4.6 & 77.7 & 3.4 & 28.3 & 150.9 \\
\hline World & 892.8 & 73.2 & 100.0 & 1236.3 & 73.4 & 100.0 & 38.5 & 0.2 & & 179.8 \\
\hline
\end{tabular}

Notes: Please see notes of Table 6.

Source: Calculations are based on the OICA's dataset.

\section{Motor Vehicle in Use across Regions}

When interpreting Table 7, one should note that 2003 and 2015 motor vehicle fleet data is unavailable, instead 2005 and 2014 motor vehicle fleet data is utilised. Data on motorisation rate per 1000 inhabitants is also just available for 2014. In addition to this, while import and export data include farm tractors, motor vehicle fleet data does not include farm tractors. Therefore, motor vehicle fleet data consists of data on passenger car and commercial vehicle fleet, which is also valid for motorisation rate per 1000 inhabitants.

Table 7 presents that size of motor vehicle fleet worldwide was more than 1.2 billion units in 2014 increased by $38.5 \%$ from about 893 million units in 2005 . $73.4 \%$ of motor vehicle fleet worldwide, in 2014 were passenger cars up by $0.2 \%$ from $73.2 \%$ in 2005 , while the remaining were commercial vehicles. In 2014, the Americas made up $32.7 \%$ of the world motor vehicle fleet decreased by $11.1 \%$ the second largest fall after Europe's amongst regions from $36.7 \%$ in 2005 still leading the Americas to have the largest motor vehicle fleet in the world in both 2005 and 2014. 57.3\% of motor vehicle fleet of the Americas were passenger cars in 2014 decreased by $6.9 \%$ the largest fall from $61.6 \%$ in 2005 leading the Americas to have the lowest share in both 2005 and 2014. Europe, in 2014 constituted $31.1 \%$ of the world motor vehicle fleet decreased by $14.3 \%$ the largest fall amongst regions from $36.2 \%$ in 2005 just lower than Americas' leading Europe to have the second largest motor vehicle fleet in the world in both 2005 and 2014. $85.8 \%$ of motor vehicle fleet of Europe were passenger cars in 2014 decreased by $0.1 \%$ from $85.9 \%$ in 2005 leading Europe to have the highest share in both 2005 and 2014. Asia-Pacific, in 2014 made up $29.6 \%$ of the world motor vehicle fleet increased by $36.5 \%$ the largest rise amongst regions from $21.7 \%$ in 2005 still resulting in Asia-Pacific having the third largest motor vehicle fleet in the world in both 2005 and 2014 [38]. 78.3\% of motor vehicle fleet of Asia-Pacific were passenger cars in 2014 increased by $7.8 \%$ the largest rise from $72.6 \%$ in 2005 still leading Asia-Pacific to have the second highest share after Europe's in both 2005 and 2014. The MENA, in 2014 constituted $4.6 \%$ of the world motor vehicle fleet increased by $28.3 \%$ the second largest rise after Asia-Pacific's amongst regions from 3.6\% in 2005 still leading the MENA to have the fourth largest motor vehicle fleet in the world in both 2005 and 2014. 74.5\% of motor vehicle fleet of the MENA, in 2014 were passenger cars increased by $3.4 \%$ the third largest rise after Asia-Pacific and Africa's from $72 \%$ in 2005 still leading the MENA to have the third highest share in both 2005 and 2014. Africa, in 2014 made up 2\% of the world motor vehicle fleet increased by $16.1 \%$ the third largest rise after Asia-Pacific and MENA's amongst regions from $1.7 \%$ in 2005 still resulting in Africa having the smallest motor vehicle fleet in the world in both 2005 and 2014 . 66\% of motor vehicle fleet of Africa were passenger cars in 2014 increased by $3.9 \%$ the second largest rise after Asia-Pacific's from $63.6 \%$ in 2005 still leading Africa to have the fourth highest share in both 2005 and 2014.

Table 7 also reports that motorisation rate (motor vehicle (passenger car and commercial vehicle) ownership) per 1000 inhabitants was 179.8 units in the world in 2014 . Europe ranked the first region with the highest motorisation rate of 495.9 units in the world in 2014. Europe was followed by the Americas having a motorisation rate of 350.6 units in the world in 2014 . Asia-Pacific had the third highest motorisation rate of 266.6 units almost half of Europe's [38]. Asia-Pacific was followed by the MENA having a motorisation rate of 150.9 units in the world in 2014. On the other hand, Africa had the lowest motorisation rate of 114.2 units in the world in 2014.

\section{Discussions}

First, this study briefly introduced the global automotive sector within its historical context with specific reference to its value chain, main parties and trends, and described government policies implemented in the automotive sector. Second, this study reported characteristics of automotive imports and exports, and cross-border trade and assembly of motor vehicles in the world and across regions. Last, this study presented motor 
vehicle sales, fleet and ownership characteristics in the world and across regions.

This study identified shifts in automotive imports and exports, and motor vehicle trade, assembly and market across regions over the last decade $[6,7,39]$. This study revealed that Asia-Pacific had displayed significant growth in terms of automotive imports and exports, and motor vehicle assembly and market over the last decade making up a larger share of the global automotive sector. Therefore, it seems that Asia-Pacific automotive sector performed better than the previous decade [5]. This study also showed that despite weaker growth in the automotive sector of the Americas, it was still a significant market for the global automotive sector. Furthermore, this study found out that Europe still prevailed the global automotive imports and exports.

It appears that Asian countries has not only developed substantial capacity in production [36, 37] but also expanded their regional markets [38]. On the other hand, it seems that Asian countries are not as much international automotive trade open as their European counterparts [8]. Therefore, there are still opportunities to improve international automotive trade across countries. It should be noted that these are the general conclusions derived from changing relative significance of regional automotive sectors rather than individual countries' automotive sectors over the last decade. Therefore, existence of economic heterogeneities across countries within regions should be considered, while conclusions are interpreted.

\section{Acknowledgements}

This study is based on my $\mathrm{PhD}$ thesis. I am indebted to Mark Casson, Nigel Wadeson, Robert Pearce and Allan Webster for their invaluable comments and suggestions on an earlier version of this study. I would also like to express great thanks to workshop participants at Reading. Furthermore, I am most grateful to anonymous referees for their very helpful comments. Funding from the Ministry of National Education of the Republic of Turkey is greatly acknowledged. All errors and views are mine.

\section{REFERENCES}

[1] D. Acemoglu. Introduction to Modern Economic Growth, Princeton University Press, Princeton and Oxford, 2009.

[2] S. Yerrabati, D. Hawkes. Economic Governance and Economic Growth in South and East Asia \& Pacific Region: Evidence from Systematic Literature Reviews and Meta-analysis, Advances in Economics and Business, Vol.3, No.1, 1-21, 2015.

[3] M.P. Timmer, et al. An Illustrated User Guide to the World
Input-Output Database: the Case of Global Automotive Production, Review of International Economics, Vol. 23, 575-605, 2015.

[4] T.J. Sturgeon, J. Van Biesebroeck, G. Gereffi. Value Chains, Networks and Clusters: Reframing the Global Automotive Industry, Journal of Economic Geography, Vol. 8, No. 3, 297-321, 2008

[5] F. Veloso, R. Kumar. The Automotive Supply Chain: Global Trends and Asian Perspectives, Asian Development Bank Institute ERD Working Paper Series No. 3, Tokyo, 2002.

[6] T.H. Klier, J.M. Rubenstein. Configuration of the North American and European auto industries - a comparison of trends, European Review of Industrial Economics and Policy, Vol.3, 1-15, 2011.

[7] B. Nag, S. Banerjee, R. Chatterjee. Changing Features of the Automobile Industry in Asia: Comparison of Production, Trade and Market Structure in Selected Countries, Asia-Pacific Research and Training Network on Trade (ARTNeT) Working Paper Series No. 37, India, 2007.

[8] D.H. Brooks, C. Hua. Asian Trade and Global Linkages, Asian Development Bank Institute Working Paper No. 122, Tokyo, 2008.

[9] P. Dicken. Global Shift: Mapping the Changing Contours of the World Economy, Guilford Press, New York and London, 2011.

[10] J.J. Flink. The Automobile Age, MIT Press, Cambridge and London, 1990.

[11] J.M. Laux. The European Automobile Industry, Twayne Publishers, New York, 1992.

[12] J. Foreman-Peck, The British Motor Industry (British Industries in the Twentieth Century), Manchester University Press, Manchester, 1995.

[13] J. Foreman-Peck. Multinationals and World Trade: Vertical Integration and the Division of Labour in World Industries, M. Casson, Editor, Allen \& Unwin, London and Boston, 1986.

[14] M. Casson. Multinationals and World Trade: Introduction and Summary, in Multinationals and World Trade: Vertical Integration and the Division of Labour in World Industries, M. Casson and et al., Editors, In association with David Barry et al., Allen and Unwin, London, Boston and Sydney, 1986.

[15] K.B. Clark, T. Fujimoto. Product Development Performance: Strategy, Organization, and Management in the World Auto Industry, Harvard Business School Press, Boston, 1991.

[16] F. Veloso. The Automotive Supply Chain Organization: Global Trends and Perspectives, Massachusetts Institute of Technology Working Paper, 2000.

[17] J. Humphrey. Globalization and Supply Chain Networks: The Auto Industry in Brazil and India, Global Networks, Vol. 3, 121-141, 2003 .

[18] D.J. Andrea, B.C. Smith. The Canada-US Border: an Automotive Case Study, Center for Automation Research, Ann Arbor, Michigan, 2002. 
[19] Automotive News. The Top 100 Global Parts Suppliers to Automakers, Detroit, Michigan, 2016.

[20] I. Ivarsson, C.G. Alvstam. International Technology Transfer through Local Business Linkages: The Case of Volvo Trucks and Their Domestic Suppliers in India, Oxford Development Studies, Vol. 32, No. 2, 241-260, 2004.

[21] J. de Melo, D. Tarr. VERs under Imperfect Competition and Foreign Direct Investment: A Case Study of the US-Japan Auto VER, Japan and the World Economy, Vol. 8, No.1, 11-33, 1996.

[22] G. Pursell. The Australian Experience with Local Content Programs in the Auto Industry: Some Lessons for India and other Developing Countries, Journal of World Trade, Vol. 35, No. 2, 379-393, 2001.

[23] W. Liu, P. Dicken. Transnational Corporations and Obligated Embeddedness: Foreign Direct Investment in China's Automobile Industry, Environment and Planning A, Vol. 38, 1229-1247, 2006.

[24] P. Pavlinek, J. Zenka. Upgrading in the Automotive Industry: Firm-Level Evidence from Central Europe, Journal of Economic Geography, Vol. 11, No.3, 559-586, 2011.

[25] A. Sonmez. Multinational Companies, Knowledge and Technology Transfer: Turkey's Automotive Industry in Focus, Springer International Publishing, Switzerland, 2013.

[26] M.V. Turker. A Model Proposal Oriented to Measure Technological Innovation Capabilities of Business Firms - a Research on Automotive Industry, Procedia - Social and Behavioral Sciences, Vol. 41, 147-159, 2012.

[27] M.T. Pamukcu, A. Sonmez. Technology Transfer in the Global Automotive Value Chain: Lessons from the Turkish Automotive Industry, in Technology Transfer in a Global Economy, D.B. Audretsch, et al., Editors, Springer, Cham, Heidelberg, New York, Dordrecht and London, 2012.

[28] J. Lorentzen. The Absorptive Capacities of South African Automotive Component Suppliers, World Development, Vol. 33, No. 7, 1153-1182, 2005.

[29] S.N. Wasti, M.K. Kozan, A. Kuman. Buyer-Supplier Relationships in the Turkish Automotive Industry, International Journal of Operations \& Production Management, Vol. 26, 947-970, 2006.

[30] J. Sutton. The Globalization Process: Auto-Component Supply Chains in China and India, in Are We on Track to Achieve the Millennium Development Goals?, F. Bourguignon, B. Pleskovic, and A. Sapir, Editors, Oxford University Press, Oxford and New York, 2005.

[31] H.K. Ansal. Technical Change and Industrial Policy: the Case of Truck Manufacturing in Turkey, World Development, Vol. 18, No. 11, 1513-1528, 1990.

[32] S.F. Karabag, A. Tuncay-Celikel, C. Berggren. The Limits of R\&D Internationalization and the Importance of Local Initiatives: Turkey as a Critical Case, World Development, Vol. 39, 1347-1357, 2011.

[33] Office of Transportation and Machinery U.S. Department of Commerce. On the Road: U.S. Automotive Parts
Industry Annual Assessment, 2011.

[34] Republic of Turkey Ministry of Economy. Automotive Parts and Components Industry (Otomotiv Ana ve Yan Sanayii Sektoru), 2012.

[35] European Commission. European Business: Facts and Figures, Office for Official Publications of the European Communities, 2009.

[36] F. Kimura, A. Obashi. Production Networks in East Asia: What We Know So Far, in Production Networks and Enterprises in East Asia Industry and Firm-level Analysis, G. Wignaraja, Editor, Springer, Tokyo, 2016.

[37] F. Kimura. International Production and Distribution Networks in East Asia: Eighteen Facts, Mechanics, and Policy Implications, Asian Economic Policy Review, Vol. 1, No. 2, 326-344, 2006.

[38] A. Hansen, K.B. Nielsen. Cars, Automobility and Development in Asia: Wheels of Change, in Routledge Studies in Transport, Environment and Development, A. Hansen and K.B. Nielsen, Editors, Routledge, Oxon and New York, 2017.

[39] M.J. Vargas da Cruz, C.F. Camargo Rolim. The Brazilian Automotive Industry in the BRICs Context: the Case of the Metropolitan Region of Curitiba, Cambridge Journal of Regions, Economy and Society, Vol. 3, No. 3, 319-334, 2010. 